\title{
How to lower the Poverty? Population Control and Increase of Asset Ownership
}

\author{
Sartika Djamaluddin \\ Universitas Indonesia \\ sartika.djamaluddin@gmail.com
}

\begin{abstract}
This study is intended to identify and analyze factors that influence the poverty rate in households in West Java. The study was carried out at three regional levels namely the provincial, district and municipal levels in West Java. This study used the model of logistic regression using the data from the national socioeconomic survey (Susenas) on household. The total number of households observed was 20.541 households. The findings indicate that control of total number of household members and asset ownership is the main factor that lowers the poverty rate in households in all regions. However factors that lower the probability of poverty in each district and municipality are varies. Another finding from the study is that financial aid from the community to support family spending is not always significant in lowering the probability of a household to be poor.
\end{abstract}

Keywords : poverty characteristic, logistic model, population control, asset ownership

\begin{abstract}
Penelitian ini bertujuan untuk melakukan identifikasi dan analisis terhadap faktor yang memengaruhi tingkat kemiskinan rumah tangga di Jawa Barat. Penelitian ini menggunakan tiga tingkatan wilayah yaitu Provinsi, Kabupaten, dan Kecamatan di Jawa Barat. Penelitian ini menggunakan regresi logistic dengan data yang berasal dari survey sosial ekononomi nasional (Susenas) rumah tangga. Jumlah rumah tangga yang diamati berjumlah 20.54 I rumah tangga. Hasil temuan mengindikasikan bahwa pengendalian jumlah anggota keluarga pada rumah tangga dan kepemilikan aset merupakan factor utama dalam menurunkan tingkat kemiskinan rumah tangga pada berbagai tingkatan wilayah tersebut. Namun, faktor yang memungkinkan penurunan tingkat kemiskinan pada tiap wilayah bervariasi. Temuan lain dari penelitian ialah bantuan keuangan yang digunakan untuk membantu pengeluaran keluarga tidak selalu berpengaruh dalam menurunkan tingkat kemiskinan rumah tangga. Keywords : karakteristik kemiskinan, regresi logistik, pengendalian populasi, kepemilikan aset
\end{abstract}

Received: March 10, 2017; Revised: May 21, 2017; Approved: June 18, 2017 
How to Lower the Poverty? Population Control...

Sartika Djamaluddin

\section{INTRODUCTION}

Within the last eightyearsperiod, the government's success in settling the issue of poverty is relatively low. The policy on poverty eradication can only reduce the poverty rate inlndonesia by 5 percent. Figure $I$ indicates that the poverty rate in 2008 up to 2013 wasquitehigh namely over 10 percent. This figure is far below the Government's optimistic target of poverty level of 8.2 percent in the RPJM within the period of 2005-2009 and tends to reach the poverty target set for the 2010-2014 RPJM namely 9 percent - 10.5 percent.

Figure. I Development of Poverty Rate at the National and West Java Level

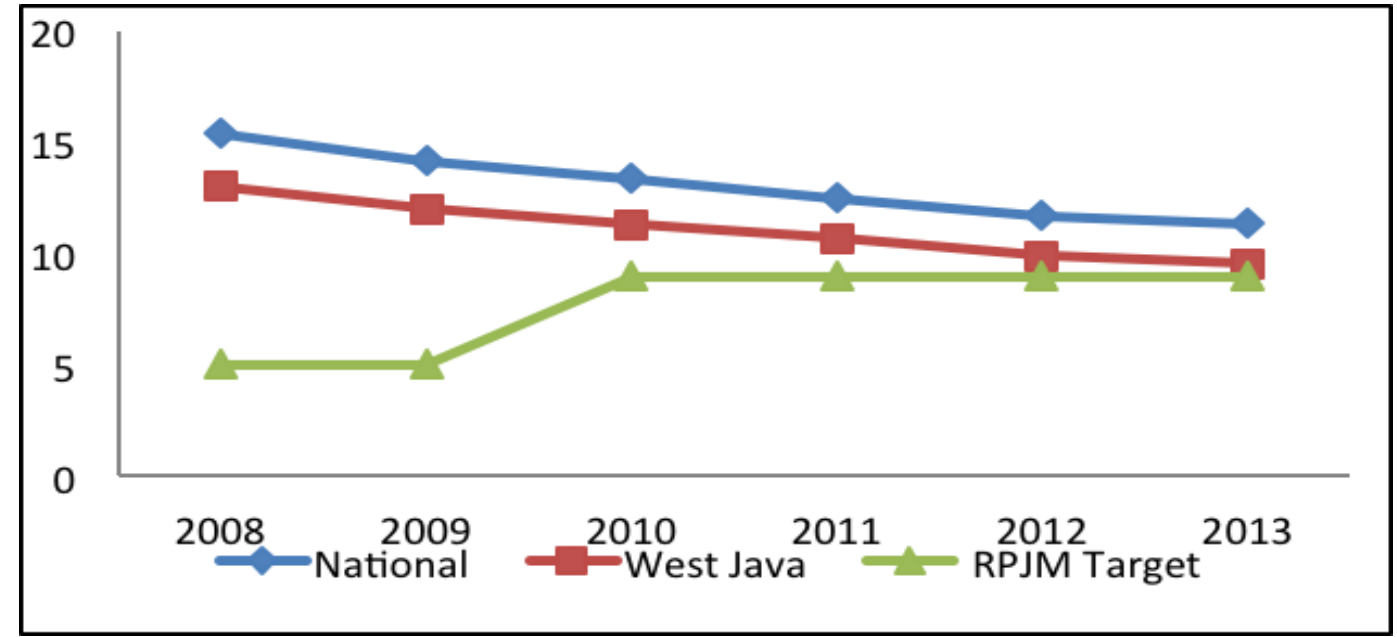

Source: BPS, processed

During the period of 2008 - 2013,the poverty rate in West Java slightly decreased. Nevertheless, the value is relatively high namelyover 10 percent on average. In 2010 the total poor population in West Java Province reached 4.7 million people, or ranked third after Central Java Province (5.3 million people) and East Java (5.5 million people). Compared to the national data, the poverty rate in West Java is relatively lower namely I 3 percent in 2008 to 9.52 percent in 2013 . Meanwhile, at the national level, the poverty rate dropped from I5.4 percent in 2008 to $1 \mathrm{I} .37$ percent in 2013.

Figure 2 shows significant change in the poverty rate from 2006 to 2010 . The poverty rate in all districts significantly dropped in $201 \mathrm{I}$. Nevertheless the poverty rate was still quite high namely around 10 percent. Several regions with relatively high poverty rate are Cirebon, Majalengka and IndramayuDistricts, BekasiDistrict, however, has relatively low poverty rate namely around 6 percent.Figure 2 indicates that the 
poverty rate in cities tends to increase in $20 \mathrm{II}$ compared to year 2006. Nevertheless, the increase is relatively insignificant. The Exception is Tasikmalaya Municipality which saw significant rise in the poverty rate namely almost 15 percent in $201 \mathrm{I}$.

Figure 2.Poverty Rate in 2006 and $20 \mathrm{I}$ I in Districts and Municipalities in West Java

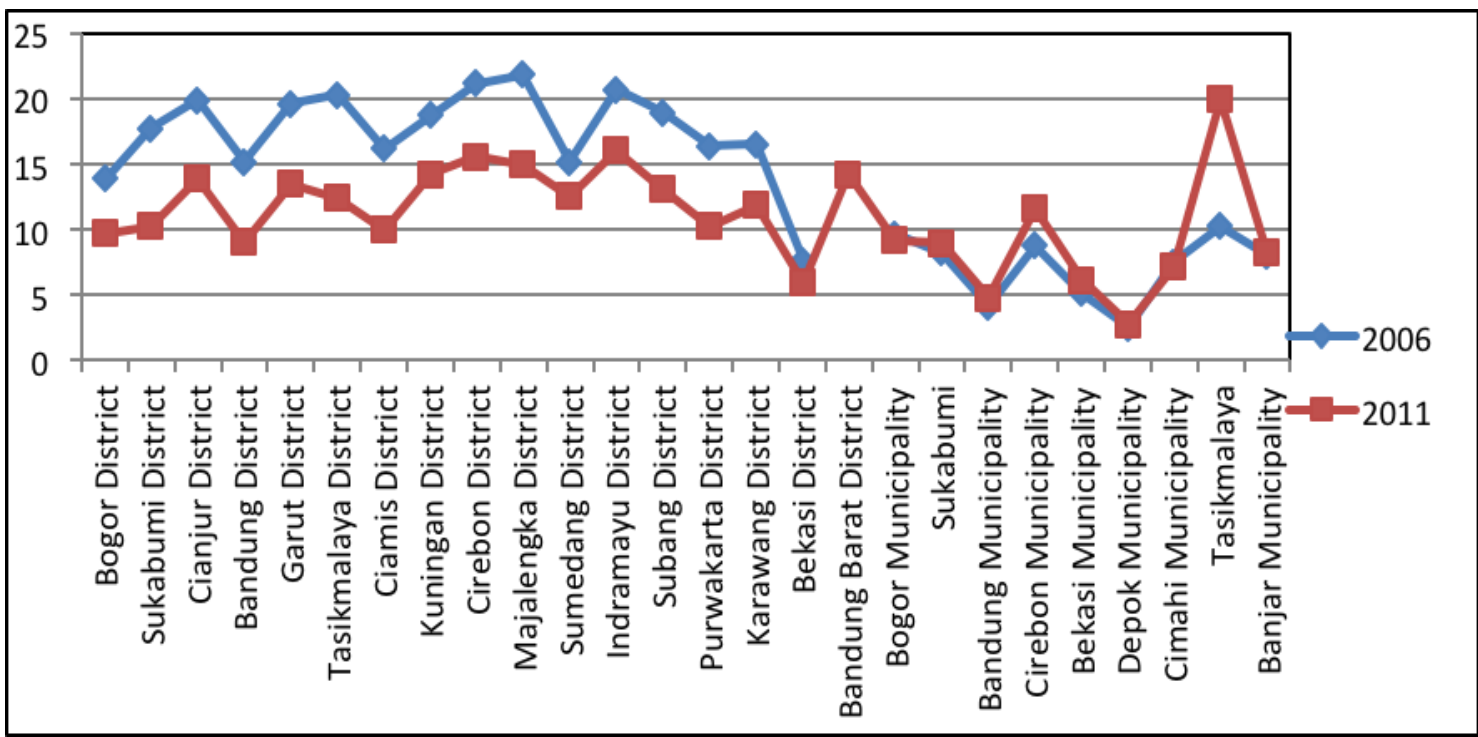

Source: BPS, processed

The difference in the level of poverty in each regionand the relatively high poverty rate in the province, districts and municipalities in West Java prompts a number of questions, such as: is the factor causing poverty different from one district to another or from one city to another? and, how complex is poverty problem in each region? This study has the purpose to identify and analyze factors that influence the poverty rate in districts and municipalities in West Java. The result of this study is expected to be able to map the factors that influence poverty based on the characteristics of the region, social, households and individuals in the observed municipalities and districts.

Studies on the determinants or factors that influence poverty in a region has been carried out many times, such as the studies conducted in Kenya (Geda, et.al, 200I), Malaysia (Mok, et.al, 2007), Malawi (Mukherjee, 1998), Indonesia (Margaretha, 2014). Studies at the district level were performed in the District of Padang Pariaman, West Sumatera (Afandi, 20II), Demak District (Sari, 20I4), districts and municipalities 
How to Lower the Poverty? Population Control...

Sartika Djamaluddin

in Banten Province (Hayati, 20I2), districts and municipalities in Central Java (Prastyo, 2010), and districts and municipalities in West Java Province (Putra, 20I4).

There are still few studies carried out to see the difference between the poverty rate in districts and in municipalities (inter municipality/city). This study will examine all factors that are deemed to influence the poverty rate in households namely region, social, households and individuals including policies on credit for enterprises and closeness in the social relation. The data used in this study is the data on micro households available from the 2010 Susenas survey. In contrast to previous studies, the research carried out in every district and municipality so that the characteristics of each region will be seen in each region.

Exposure to literature review related to the factors that cause poverty and relevant previous studies. The research method describes the framework and the stages of research, variables, data and regression models were used. Results of the study are described in three parts: factors that affect poverty at the provincial, district and municipality.

\section{POVERTY FACTOR}

The factor of poverty or factors that have strong correlation with poverty can be classified into 4 factors namely the factors of regional characteristics, social characteristics, household and individual characteristics (Haughton\& Khandker,2009). Regional characteristics are the geographical characteristic or condition of a region. Regional characteristics include the factors of isolation and remoteness of the region (including limited infrastructure and bad market access and services), natural sources, weather, government policies and gaps. The poverty rate is generally high in isolated regions. The households living in isolated areas do not have sufficient physical infrastructure to adequately support their economic activities. Job possibilities and opportunities become limited and their incomes tend to be low. Government policies play very important role in poverty eradication. In addition to aid programs and social protection for families and empowerment of people's potentials, the government provides aids to empower micro, small-, and medium-scale enterprises (SMEs). SMEs usually find it difficult to get financial access because they do not meet banking requirements, while this type of business has the potency to provide employment for poor households. Through this program the government opens and provides access to 
capital and economic strengthening. Such efforts are expected to accelerate creation of businesses and poverty eradication.

The community characteristics reflect the characteristics or condition of the environment where the household lives. The community characteristics such as the infrastructures of electricity, roads, paths, bridges, conduits and so forth, land distribution, access to public facilities (distance to the school, hospital), social structure and social capital also play the role in influencing the poverty rate. The limited power line that can be enjoyed by households may disrupt household activities, education, health and social activities. Poor road condition may disrupt distribution of goods and economic activities.

The characteristics of households and individual affect the poverty rate. The characteristics of household include the number of members in the household, dependency ratio, sex, assets, work and income structure, type of work, average level of health and education of the members of the household et cetera. Low level of education and poor health condition cause the family to face limited job choices. The income they earn is in general low hence it is difficult for them to meet their minimum needs. A Large number of household members increase the burden of the head of the household because the minimum needs that should be met by the head of the household are increasingly high. The issue of poverty is closely related to the issue of gender. The research by the International Labour Organization (ILO) 2004 reveals that women tend to be poorer than men, as among others women often work on agricultural field that have low productivity, receive lower wages for the same job, have no rights that guarantee the land they cultivate on, lower education, limited access to medical facilities and have heavier burden in household chores.

Empirically, there are a number of studies carried out to examine the factors of poverty. The studies by Geda, et.al (200I) examined the factors of poverty in Kenya. This study concludes that poverty closely relates to the level of education, the size of household and agricultural activities. The study used the data on households in year 1994 with the model of binomial regression and polychotomous logit. Mok, et.al (2007) examined the factors of urban poverty in Malaysia. This study concludes that human capital significantly lowers the probability of poverty while migrant laborers are more vulnerable to poverty. Human resources significantly lower poverty rate in 
How to Lower the Poverty? Population Control...

Sartika Djamaluddin

Malaysia.The size of household, ethnic group and religion are the important factors that reduce poverty in Malaysia. This study used 2,403 households in urban areas froms 2004 up to 2005. The study by Mukherjee (1998) concludes that high education level especially for women and reallocation of manpower from the agricultural sector to the trade sector will be effective in lowering poverty rate in Malawi. Gibson (1999) in Haughton \& Khandker (2009) explains that the survey by the Cambodia SocioEconomic Survey(CSES) in 1934 - 1994 indicates that poor households tend to live with higher size of household. On average the size of one houshold is $6-7$ members, while, the richest households have 4-5 members.

\section{Figure 3. Poverty Factors}

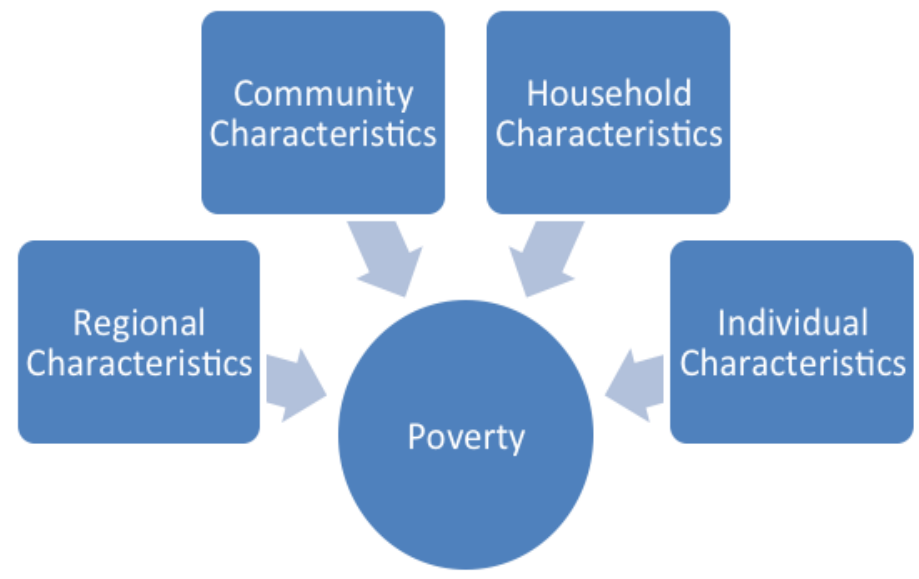

The study by Afandi (20II) in Padang Pariaman District reveals that the characteristics of households that are most influential in increasing the probability of households to become poor are the those with the total number of more than four people in one household, the floor total area of less than $8 \mathrm{~m} 2$ per capita, the age of head of family of less than 35 years, utilizing the facility of business credit, and family heads working in the sectors other than agriculture and industry. The study by Hayati (20I2) reveals that the geographical location and addition of the number of household members cause the risk of poverty high in households in municipalities and districts in Banten Province. The study by Sari (2014) finds that asset ownership, work, and number of dependants are the major factors for poverty in Bonangsub district, Demak District. The study by Usman, Sinaga and Siregar (2006) examine changes in poverty determinants in Indonesia before and after fiscal decentralization. One of the findings on this study is that the (social) community factor experienced a change from 1999 to 2002. The condition of road infrastructure exacerbated in 2002 as compared to 1999. 
The Government needs to observe the sectors of agriculture, education, health and infrastructure.

\section{METHOD}

In accordance with the purpose above, this study is conducted through these following stages. The first stage is preparing the hypotheses. The researcher assumes that the regional, social and household characteristics significantly influence the household poverty rate in municipalities and regencies. The second stage is defining and measuring poverty. The measurement of poor household is based on the poverty line defined by the government. The poverty line refers to the level of income that enables a household to meet its minimum basic needs. Poor households are those whose income is below the poverty line. Their income is so low that it incapacitates them to meet their minimum basic needs. This poverty line is different in each city and district. The per capita income is estimated from the per capita consumption rate.

The next stage is to define the factors, which are theoretically assumed to cause or influence poverty. These factors include regional, social, household, and individual characteristics. Regional characteristics represented by the level of isolation, government policies, and the region's infrastructure. Community characteristics represented by kinship and networks existing among the community. Household and individual characteristics include types of employment, asset ownership, employment status, size of household, education, and health. The fourth step is data modeling and processing. The applied model is the logit model, which enables us to see the influence of regional, social, household and individual characteristics on the probability of household poverty. The result of research may identify factors causing the probability of household poverty high or low. The concept of probability of household poverty is applied because that researcher does not directly interview poor households and asking the cause of their poverty. The researcher assumes the factors theoretically influencing poverty in households and examines it in the model. The data used in this research is extracted from the Susenas' data on household and individual scores. Both sets of data are presented separately by BPS. For the purpose of this study, the data is first combined into one set of data. The fifth stage is the result analysis. In this stage the influence of regional, social, household, and individual characteristics on the probability of household poverty in provinces, regencies, and cities is analyzed. 
How to Lower the Poverty? Population Control...

Sartika Djamaluddin

The empirical model used is the logistic regression model where the dependent variable is binary, which equals $I$ if the household is proven to be poor and 0 otherwise. $\mathrm{Pi}$ is the probability of the $-\mathrm{i}$ household to stay under the poverty line. Xki is the independent variable namely the $\mathrm{k}$ characteristic of household $\mathrm{i}$.

The empirical data for dependent and independent variables is obtained from Susenas data on West Java households and individuals in 2010 published by BPS. The total observation covers 20,54I households in 26 regions consisting of 10 municipalities and 16 districts. The dependent variable is poverty status. This is the binary variable with the value of $\mathrm{I}$ if the household per-capita revenue comes below the poverty line. The independent variable includes:

Regional characteristics include the variables of isolation level and government policy. The isolation level variable is derived from the region where the household resides. If the household lives in urban area, be in a city/district, the variable equals $I$. On the other hand, if the household lives in rural area, be in a city/district, the variable equals 0 . Urban and rural areas can be found in both cities and regencies. This variable is denoted as "Region". The variable of policy is represented by the policy of credit for enterprises in the form of PNPM mandiri program and or other government programs and/ or Credit for Small Enterprises (KUR) and/ or bank programs other than KUR and/ or cooperatives program. This policy is aimed at households that have businesses, be poor or non-poor households. This variable is denoted as "Kredit_Usaha" of Credit for Enterprises. This variable has the value of $I$ if the household receives one or more credit for enterprises and has the value of zero if it receives none of those.

Social characteristics are represented by the variable of sources of livelihood. This variable represents the role and participation of the community in helping others' economy. This variable has the value of $\mathrm{I}$ if the source of livelihood comes from the household itself or internal source such as savings, personal belonging trade, or mortgage. This means such household is independent enough for not receiving economic assistance from others. This variable has the value of 0 if the financing source comes from loan from relatives/family, loan from friends/neighbors, from mortgage, cash loan from bank, or from the cooperatives. This variable is denoted as “Sumber_Biaya_Hidup" or Source of Livelihood. 
Household characteristics represented by the total members in the household and asset ownership. The variable of total members in the household is denoted as "Jart". "Asset" variable represents ownership of assets by the household. This variable has the value of $I$ if the household possesses bicycle or motorcycle or boat or motorboat or refrigerator or $12 \mathrm{~kg}$ or more LPG natural gas cylinder, 0 otherwise.

Individual characteristics are represented by the types of employment, job status, education and health level. "Agricultural" variable represents the types of employment from which the household receives the main income. This variable has the value of $\mathrm{I}$ if the household engages in agricultural or horticultural or plantation or fishery or farms or forestry businesses and other types of agriculture or mining and quarrying or processing industry, 0 otherwise. Employment status is represented by "Laborer" variable. This variable has the value of I if the household's employment status is laborer/employee, 0 otherwise. The educational level of a household is measured from the latest diploma owned. This variable is denoted as "Low education". This variable has the value of $\mathrm{I}$ if the household does not own any diploma or owns Elementary/Special Elementary School diploma or Madrasah Ibtidaiyah or Package A certificate or Junior High/Special Junior High School diploma or Madrasah Tsanawiyah or Package $B$ certificate and it has the value of 0 . Health level is measured from how often one complains about illness and gets medication. This variable is denoted as "Outpatient treatment". This variable has the value of I if the household member has ever received medication for the last 6 months, 0 otherwise.

\section{RESULT AND DISCUSSION}

\section{The Data of Poverty in West Java}

Based on Susenas data of 2010, the number of households under the poverty line reaches 945,172 households or almost 9 percent of the total existing households. Poor households spread in 17 districts and 9 municipalities. The highest poor household percentage is in Tasikmalaya Municipality, Indramayu District, Majalengka District, and Kuningan District. The poverty rate in those regions reaches 12 percent or more. The lowest poor household percentage, namely less than 5 percent, is in Bekasi District, Bekasi Municipality, Bandung Municipality, Cimahi Municipality, and Depok Municipality. The poverty rate in other regions is between 5 and II percent. 
How to Lower the Poverty? Population Control...

Sartika Djamaluddin

The heads of poor households with productive age namely between 20-55 years olds exceed 72 percent. Most of them live in rural areas in cities and districts. Poor households in regions with high poverty rate like Tasikmalaya Municipality, Indramayu District, Majalengka district, and Kuningan District, are mostly above 55 years old. Meanwhile, regions with low poverty rate such as Bekasi District, Bekasi Municipality, Bandung Municipality, Cimahi Municipality, and Depok Municipality habited by heads of poor households within their productive age. The proportion of those households living in rural and urban areas is almost the same. 54 percent live in rural areas and the rest live in urban areas.

The Susenas data 2010 indicates that the spread of poor households varies in cities and regencies. Table I. Shown that the highest percentage of poor households is in Tasikmalaya municipality where their number exceeds 17 percent of the total households existing in this region. Other regions with high poverty rate are the Districts of Majalengka, Indramayu, Kuningan, Cianjur, Cirebon and Bandung Municipality with the poor household percentage of above 10 percent. Meanwhile, the quite low poverty rate (below 5 percent) covers Depok Municipality (I.8 percent), Bandung Municipality (3.I percent), Bekasi Municipality (4.I percent) and Bekasi District (4.4 percent).

Based on the classification of residential area, most households live in rural areas. Male heads of households living in rural areas are 455,068 or 53 percent and female heads of households are 50,370 (54.8 percents). The number of poor households in rural and urban areas does not differ significantly. It indicates that the number of poor households living in urban areas is relatively high. Urban areas are characterized by the availability of public facilities such as kindergartens, junior and senior high schools, markets, stores, cinemas, hospitals, hotels, billiard, club, massage parlors, beauty shops, electricity and phone service. Poor households living in districts are mostly located in rural areas with minimum public facilities. On the other hand, poor households in cities are mostly located in urban regions. This indicates that access to public facilities for poor households in districts is more limited than that of poor households in cities. An exception is in Cirebon District where poor households mostly live in urban areas. 
Nowadays, poor households spread in both rural and urban areas. The Susenas data year 2010 shows that the spread of poor households is almost prevalent and similar in number in urban and rural areas in West Java Province. There are 505,438 poor households in rural areas and 439,735 in urban areas. The heads of households are mostly dominated by male. There are 853,313 male heads and 91,854 female heads. Loan extension for business to poor households is very small in number. There are 996,877 households receiving credit for enterprises. 96.3 percent of which is categorized as non-poor households and the other 3.67 percent is poor households. The districts which poor household receive credit for enterprises the most are Sumedang, Tasikmalaya, Garut, and Sukabumi. At the municipal level, the recipients of the credit for enterprises the most i.e. Tasikmalaya, Bandung and Banjar Municipalities.

Table I. Heads of Poor Household' Gender in West Java

\begin{tabular}{llll}
\hline Sex & Rural & Urban & Total \\
\hline Female & 50,370 & 41,485 & 91,855 \\
Male & 455,068 & 398,250 & 853,318 \\
Total & 505,438 & 439,735 & 945,173
\end{tabular}

Source: Susenas 2010, processed

Most poor households finance their living costs from external assistance such as loan from relatives, neighbours or other kinds of loan. Only in Karawang District, Bandung Municipality and Bekasi Municipality, most of their poor households can still finance themselves. This condition indicates that community's supports or assistance towards poor households are still quite high.

Susenas Data 2010 indicates that 82.6 percent of poor households own their own houses, most of who live in rural areas. There are 163,809 households accounted for not having houses, 72.6 percent of which live in urban areas. This fact can be seen in most districts and municipalities in West Java. In Bandung Municipality, most of poor households do not own houses. In Bekasi Municipality, the poor households having houses and not having houses are almost the same in number. Other house characteristic is that the houses of poor households generally have concrete floor, not ground or bamboo floor (8I.6 percent).

Poor households spreading in rural and urban areas tend to have large number of members. Around 60 percent of them have members between $3-5$ individuals, 29 
How to Lower the Poverty? Population Control...

Sartika Djamaluddin

percent have $6-8$ individuals, and 4.2 percent have more than 9 members. This large number of family members demonstrates the burden of the head of household has to bear. The majority of poor households living in clusters I, 2, and 3 have $3-5$ members, except in Depok and Bekasi Municipality, where most poor households have $6-8$ members.

Most poor households do not have any assets (62.4 percent). Only 355, I 42 households have own assets. The major assets they own are refrigerators, $12-\mathrm{kg}$ or more LPG cylinders, and boats. To cover their daily living costs, both on food and others, poor households rely on others' help. 15 percent of poor households finance their daily cost by borrowing money from their family/relatives, 22.67 percent from their neighbors, 12.7 from their own savings. There are also households using money from money-lenders ( 4.4 percent). The remainders get funds from banks, cooperatives or from by pledging their personal belongings. There are 382 households financing their living costs from other financing sources. The households supporting their daily needs from other financing sources (from work) are quite prevalent in Bogor District, Sukabumi District, Cianjur District, Bandung Municipality and Tasikmalaya Municipality.

The poor households' school enrolment is still low. Susenas data indicates that 9 percent of poor household heads never receive formal education. The other 91 percent are those who are no longer at school. No poor household head is still at school. Poor households are still not free from illiteracy, as there is 9.8 percent illiterate. Poor households rarely interact with technology. Most of them do not have access to the Internet. Only 0.48 percent of them accessed the internet in the last 3 months. 93 percent of household heads that are not at school anymore evidently received only primary education. The highest level they have received/ are receiving is the elementary school/junior high school or the equivalent. Most of them finished school. However, around 26 percent did not complete elementary school or do not have elementary school certificates.

The fact that poor households mostly have low level of education occurs in every city/ district. In Depok Municipality, the percentage of poor households with low educational level or none is almost the same. This means that the number of poor households with the level of education above primary is quite high. As many as 314,192 household heads or around 33.2 percent of poor households complain about disease in 
the last I month. The diseases they most suffered are categorized as serious and some other diseases such as measles, ear watery / jaundice / liver / convulsions, paralysis, dementia, accidents, etcetera. Other diseases they suffered include coughs, colds and recurring headaches. The awareness of poor households to seek treatment when they have disease is relatively low at 43.7 percent. The rest do not seek treatment.

The illnesses turned out to affect the activities of the household. A total of 55.3 percent of household heads' work, schools and other activities are disrupted. However, not all of them have awareness to seek treatment, as only 88.5 percent check their condition to medical personnel. Households without any bothered activities prefer not to seek treatment (44.67 percent). This is likely due to the economic demands that require them to keep working. Their awareness to seek treatment when there are pains is relatively low namely 43.7 percent. Complaints of having illness in I month are more common in households living in rural areas than in urban areas.

The number of unemployed poor households reaches 11.8 percent. Their activities are among other dealing with housewifery. Some of them look after the households while others do many different activities such as sport, additional course, picnic, and social activities (organization, community service) and many more. The percentage of unemployed poor households is relatively high in areas with high household poverty rate such as Majalengka district, Sukabumi district, and Cimahi Municipality. Poor households living in districts mostly work in the agricultural sector. Meanwhile, poor households in cities mostly work in the service sector, construction, and trade as seen in the Municipalities of Bogor, Sukabumi, Cirebon and Bekasi.

There are 833,706 poor households engaging in 4 different kinds of business. The agricultural fields include rice and crop agriculture, horticulture, plantation, fishery, livestock, forestry and other agricultural fields. Mining fields include mining and quarrying, manufacturing, electricity and gas. Trade fields include construction/building, trade, hotels and restaurants. Service field consists of transportation and warehousing, information and construction, finance and insurance, education services, health services, social services, government and individuals and others. The sector of agriculture and trade remains the key sector that absorbs laborers from poor households. 
How to Lower the Poverty? Population Control...

Sartika Djamaluddin

For employment status, most poor households work as casual workers (34.5 percent) entrepreneurs (22.5 percent), laborers/ employees/personnel (20.5 percent) and unpaid workers (20 percent). Most poor households with laborer status live in the Municipalities of Bogor (I0.38 percent), Cianjur (6.5 per cent), London (6.8 per cent) and Garut (7 percent). Only a few poor households have health insurance. There are more that 50 percent of poor households without any insurance protection. Poor households using JPK / MM / Kartu Sehat / Gakin / Kartu Miskin / Jamkesnas card are 35.7 percent, I.8 percent JPK Jamsostek, other JPKM/JPK 0.65 percent, JPS PNS / Veterans / Retirement 0.58 per cent.

\section{Factors Influencing Poverty in West Java Province}

The result of logistic regression in Table $2 \mathrm{a}$ indicates that all factors (regional, social, household, and individual) significantly influence the poverty rate in West Java Province. Several findings from the regional aspect show that households in urban areas relatively have small poverty probability compared to those in rural areas. The probability of a household to be considered poor in urban areas is 0.5 times lower than the probability of being poor if they live in rural areas. Another factor that plays an important role in the decline of poverty probability is the policy of credit for enterprises. This policy is proven to be significantly capable in reducing the probability of household poverty. The probability of poverty for households receiving credit for enterprises is 0.5 times compared to households not receiving.

The factor of household independence is proven to lower the probability of household to be in poverty. The poverty probability of households financing their daily living cost independently is 0.88 times lower than those financing their living cost with external assistance. Other factors such as the size of the household and asset ownership also have significant impact on the poverty rate. The larger the size of a household, the higher the chance of household to be poor. On the other hand, the more a household owns assets, the lower its chance to be poor. The poverty probability of households owning assets is 0.32 times lower than those not owning assets.

The economy factor shows that households engaging in agriculture and working as laborer have a relatively high possibility to be in poverty. The poverty probability of households engaging in agricultural fields is 1.68 times than those engaging in other 
fields. Meanwhile, laborers have I.2 poverty probability compared to other kinds of employment. The poverty probability of households with low (basic) education is relatively high namely 2.1 as compared to those with secondary and higher education. The health factor also plays an important role in influencing the probability of poverty. The poverty rate of households with less health complaints (getting medical assistance every 6 months) is relatively low namely 0.85 times.

\section{Factors Influencing Poverty in Districts}

Table $2 a$ and $2 b$ indicates the estimated factors influencing poverty rate in districts. These factors vary in each district. The influence of regional classification on the poverty rate is commonly significant with low probability of poverty. Therefore, households in urban areas in the districts of Bogor, Sukabumi, Cianjur, Bandung, Garut, Tasikmalaya, Kuningan, Indramayu and Purwakarta have relatively low probability to be in poverty. Meanwhile, the poverty rate in northern and western districts such as Cirebon, Majalengka, Sumedang, Subang, Karawang, Bekasi and West Bandung is proven to have no correlation with regional classification. The success of credit for enterprises program minimizes the poverty rate in several districts namely Bogor, Bandung, Tasikmalaya, Ciamis, Majalengka, and Indramayu. Households receiving credit for enterprises in those districts have a relatively low probability of poverty. The credit for enterprises is used to develop micro-enterprises that can augment the households' income.

The influence of economic independence on poverty probability is seen in most northern and western districts namely Garut, Cirebon, Indramayu, Subang, Purwakarta, Karawang and West Bandung Districts. The findings in most districts reveal that households capable of financing their daily needs by themselves have lower probability of poverty, except for Purwakarta and Karawang Districts. The poverty probability for households in Purwakarta and Karawang Districts is relatively high if they depend only on their own incomes to finance their daily needs. This finding is interesting since Purwakarta and Karawang are included into West Java's Industrial areas. The living cost in those areas is relatively higher compared to in other districts. Relatively high living cost compared to their incomes incapacitates households to meet their minimum daily basic needs with their own income. 
How to Lower the Poverty? Population Control...

Sartika Djamaluddin

All household characteristics including the size of household and asset ownership are significant and have the same direction in all districts. The poverty probability for households with large members is relatively higher. Meanwhile, households with asset ownership have low probability for poverty. The influence of poverty characteristics namely employment, educational level and health vary in each district. The influence of types of household employment on poverty is seen in most districts. Households with members working in agricultural activities in general have high probability for poverty. This conclusion is seen in the districts of Sukabumi, Cianjur, Garut, Kuningan, Cirebon, Subang, Bekasi and West Bandung.

However, particularly in Karawang District, households working in the agricultural sector have low probability to be poor. This indicates that the possibility of farmers' incomes in Karawang district is relatively high as compared to the incomes of farmers in the districts of Sukabumi, Cianjur, Garut, Kuningan, Cirebon, Subang, Bekasi and West Bandung. The influence of employment status to poverty is only seen in two districts namely Garut District and West Bandung District. The households whose members work as laborers have relatively high probability to be in poverty.

Empirical evidences show that the influence of educational level to poverty can only be seen in 5 districts namely Bogor, Sukabumi, Bandung, Sumedang dan BekasiDistricts. The Households with low educational level have high probability to be in poverty. Health condition influences the poverty rate in several districts in different ways. In the districts of Karawang and Tasikmalaya, the households with relatively good health condition have relatively low poverty rate. Meanwhile in the districts of Sukabumi and West Bandung, the households with relatively good health condition have relatively high poverty rate.

\section{Factors Influencing Poverty in Urban Areas}

Table $2 c$ indicates the factors that may influence poverty in cities. The influence of regional classification in urban areas and rural areas are not apparent in all municipalities. This is because almost all municipalities have no rural areas. In other words all areas in municipalities are included in the category of urban areas, except several regions such as Tasikmalaya and Banjar Municipalities that still have rural areas. The result of data processing reveals that the households that live in urban 
areas in Tasikmalaya and Banjar Municipalities have lower probability to be in poverty.

The influence of credit for enterprises on poverty can only be seen in TasikmalayaMunicipality. Meanwhile the data for other municipalities is not sufficient to prove the correlation. The households that participate in the program of credit for enterprises in Tasikmalaya have relatively low probability to be in poverty. The influence of type of expenses for daily needs is significant in several regions namely the Municipalities of Bogor, Bandung, Bekasi, Tasikmalaya dan Banjar. The households that finance their daily needs only from their incomes and assets have high probability for poverty as compared to those who have the probability to have access to funds from outside sources (neighbors, banks, credit or etc). This is not surprising considering relatively high living costs in municipalities as compared to in districts. This is, however, not the case in TasikmalayaMunicipality. The households that can independently support their daily needs have lower probability to be in poverty.

All household characteristics namely the significant size of household and asset ownership have influence in the same direction in all municipalities. The probability of household poverty is high in families with higher number of members. Meanwhile, the households that have assets have low probability of poverty. The influence of types of business on the poverty rate generally cannot be seen in cities except in Bandung Municipality and Tasikmalaya Municipality. This may be caused by increasingly narrow agricultural land and less and less households working in this sector. In the municipalities of Bandung dan Tasikmalaya, the households working in the business of agriculture have higher probability for poverty as compared to those working in other businesses. The same is true for the influence employment status on poverty. Empirical evidence can only be seen in Tasikmalaya Municipality where the households that have the status as laborers have high poverty rate.

The influence of educational level on poverty is seen in almost all municipalities. Low educational level increases the probability of poverty in the municipalities of Bogor, Sukabumi, Bandung, Cirebon, and Bekasi. Meanwhile, low educational level apparently reduces the probability of poverty for households in Tasikmalaya Municipality. It is assumed that the need for qualified manpower is relatively low in 
How to Lower the Poverty? Population Control...

Sartika Djamaluddin

Tasikmalaya Municipality compared to in other municipalities, hence the households with low educational level can be employed and earn decent income.

The influence of health condition on the poverty rate is only evident in three municipalities. In the municipalities of Bandung and Tasikmalaya, the poverty rate of households with relatively good health level (visiting health facilities in the last 6 months) is relatively lower. Meanwhile, the probability of poverty in Depok Municipality increased instead. This is possible because the households visiting health facilities once in 6 months are deemed to reflect poor health condition thus increase the probability of poverty.

\section{CONCLUSION}

Principally, all factors of region, social, household, and individual influence the poverty rate of a municipality/district. If the Government is serious in eradicating poverty, they should use these factors as reference in improving policy on poverty. If each characteristic is deemed to have the same weight, the complexity of poverty can be seen from how many factors/characteristics that have influence on the poverty rate in districts/municipalities. The region with very high complexity of poverty is Tasikmalaya Municipality where the regional, social, household dan individual characteristics significantly influence poverty in this municipality. This fact is in line with the fact that the poverty rate in Tasikmalaya municipality in 2010 was the highest among all district sand municipalities. The Central Government is expected to play a greater role in assisting the regional government to settle complex poverty problems.

Large number of household members and asset ownership are the factors that influence the poverty rate in all municipalities and districts. The policy implication of this finding is the need for focus on the policy to control birth by government in all levels. The same is the case for asset ownership.If a household can set aside high portion of expenditures for investment, such as for buying assets, the probability for household poverty can lower. In addition, the Government is also expected to provide facility to households to own assets. 


\section{REFERENCES}

Afandi, W.N. (20II). Identification of Poverty Characteristics of Household in Padang Pariaman District, (Case study: Nagari Malai V Suku). (Unpublished Thesis). Padang: Program Pascasarjana Universitas Andalas.

Geda, A., N.D. Jong., G. Mwabu \& M.S. Kimenyi. (200I). Determinant of Poverty in Kenya: Household Level Analysis. Working paper, Institute of Social Studies.

Hayati, A. (20I2). Änalisis Resiko Kemiskinan Rumah Tangga di propinsi Banten (Analysis of the Risks of Household Poverty in Banten Province). (Unpublished Thesis). Depok: Universitas Indonesia.

Haughton, J. \& S.R. Khandker. (2009). Handbook on Poverty and Inequality. New York: The Worldbank.

Margaretha, C. (2014) Faktor-faktor yang mempengaruhi Status Rumah Tangga Miskin di Indonesia (Factors Influencing the Status of Poor Households in Indonesia), (Unpublished Thesis). Depok: Universitas Indonesia.

Mok T.Y., C. Gan and A. Sanyal. (2007). The Determinants of Urban Household Poverty in Malaysia. Working Paper. Cartenbury: Lincoln University.

Mukherjee, S. (1998). The Determinant of Poverty in Malawi. Bangkok: International Labour Organization.

Prasetyo, A.A. (20I0). Analisis Faktor-Faktor yang Mempengaruhi Tingkat Kemiskinan: Studi kasus 35 Kabupaten/Kota di Jawa Tengah tahun 2003 - 2007 (Analysis of Factors influencing Poverty Rate: Case study, 35 Districts/Municipalities in Central Java years 2003 - 2007). (Unpublished Thesis). Semarang: Universitas Diponegoro.

Putra, M.M.D. (20I4). Determinan Kemiskinan di Kabupaten /Kota Propinsi Jawa BaratTahun 2008 - 2012 (Determinants of Poverty in Districts/Municipalities in West Java Years 2008-2012). (Unpublished Thesis). Depok: Universitas Indonesia. Sari, A.C.D.M. (20I2). Pengaruh kepemilikan Aset, Pendidikan, pekerjaan dan jumlah tanggungan Terhadap kemiskinan rumah tangga di Kecamatan Bonang, Kabupaten Demak (Influence of Asset Ownership, Education, Work and Number of Dependants on household poverty in Bonang Sub-District, Demak District). (Unpublished Thesis). Semarang: Universitas Diponegoro. 
How to Lower the Poverty? Population Control...

Sartika Djamaluddin

Usman, B.M.S. \& H. Siregar. (2006). Analisis Determinan Poverty Sebelum dan sesudah

Desentralisasi Fiskal (Analysis of the Determinants of Poverty before and after Fiscal Decentralization). Working Paper. Institut Pertanian Bogor. 


\section{Appendix}

Table $2 \mathrm{a}$

Logistic Estimation: Province, Distric and Municipality

\begin{tabular}{|c|c|c|c|c|c|c|c|c|c|}
\hline Variables & Province & Bogor & Sukabumi & Cianjur & Bandung & Garut & Tasikmalaya & Ciamis & Kuningan \\
\hline \multicolumn{10}{|l|}{ Regional characteristics } \\
\hline Region & $* * S-$ & $* * S-$ & $* * S$ & **S- & $* * \mathrm{~S}$ & $* * \mathrm{~S}-$ & $* * S$ & $* * \mathrm{~S}$ & $* * \mathrm{~S}-$ \\
\hline \multicolumn{10}{|l|}{ Credit for } \\
\hline Enterprises & **S - & **S - & NS & NS & $* * \mathrm{~S}$ & NS & $* * S$ & $* * \mathrm{~S}$ & NS \\
\hline \multicolumn{10}{|l|}{ Social Characteristics } \\
\hline Source of Livelihood & *S - & NS & NS & NS & NS & $* * \mathrm{~S}-$ & NS & NS & NS \\
\hline \multicolumn{10}{|l|}{ Household Characteristics } \\
\hline Jart & $* * S+$ & $* * S+$ & $* * S+$ & $* * S+$ & $* * S+$ & $* * S+$ & $* * S+$ & $* * S+$ & $* * S+$ \\
\hline Assets & $* * S-$ & $* * S-$ & $* * \mathrm{~S}$ & **S- & $* * \mathrm{~S}$ & $* * S-$ & $* * \mathrm{~S}-$ & $* * \mathrm{~S}-$ & $* * \mathrm{~S}-$ \\
\hline \multicolumn{10}{|l|}{ IndividualCharacteristics } \\
\hline Agricultural Lapus & $* * S+$ & NS & $* * S+$ & $* * S+$ & NS & $* * S+$ & NS & NS & $* S+$ \\
\hline EmploymentStatus & $* * S+$ & NS & NS & NS & NS & $* * S+$ & NS & NS & NS \\
\hline Low Education & $* * S+$ & $* S+$ & *S+ & NS & $* * S+$ & NS & NS & NS & NS \\
\hline Outpatient treatment & $* * S-$ & NS & $* S+$ & NS & NS & NS & $* * S-$ & NS & NS \\
\hline Constant & $* * \mathrm{~S}-$ & $* * \mathrm{~S}$ & $* * S$ & **S- & $* * \mathrm{~S}$ & $* * \mathrm{~S}-$ & $* * \mathrm{~S}-$ & $* * \mathrm{~S}$ & $* * \mathrm{~S}$ \\
\hline
\end{tabular}

Note $: S=$ Significant, NS $=$ Not Significant, $* *$ significant $5 \%, *$ significant $10 \%$

Tabel $2 b$

Continued

\begin{tabular}{|c|c|c|c|c|c|c|c|c|c|}
\hline Variables & Cirebon & Majalengka & Sumedang & Indramayu & Subang & Purwakarta & Karawang & Bekasi & $\begin{array}{c}\text { West } \\
\text { Bandung }\end{array}$ \\
\hline \multicolumn{10}{|l|}{ Regional characteristics } \\
\hline Region & NS & NS & NS & $* * \mathrm{~S}-$ & NS & **S- & NS & NS & NS \\
\hline Credit for Enterprises & NS & $* * S-$ & NS & *S- & NS & NS & NS & NS & NS \\
\hline \multicolumn{10}{|l|}{ Social Characteristics } \\
\hline $\begin{array}{l}\text { Source of Livelihood } \\
\text { Household } \\
\text { Characteristics }\end{array}$ & **S- & NS & NS & $* * S-$ & $* * S-$ & $* * S+$ & $* * S+$ & NS & $* * S$ \\
\hline Jart & $* * S+$ & $* * S+$ & $* * S+$ & $* * S+$ & $* * S+$ & $* * S+$ & $* * S+$ & $* * S+$ & $* * S+$ \\
\hline Assets & $* * S-$ & $* * S-$ & $* * S-$ & $* S-$ & $* * S-$ & $* * S-$ & $* * S-$ & $* * S-$ & $* * \mathrm{~S}-$ \\
\hline \multicolumn{10}{|l|}{ IndividualCharacteristics } \\
\hline $\begin{array}{l}\text { Agricultural } \\
\text { Employment }\end{array}$ & $* * S+$ & NS & NS & NS & $* * \mathrm{~S}+$ & NS & $* * S-$ & $* * S+$ & $* * S+$ \\
\hline Status & NS & NS & NS & NS & NS & NS & NS & NS & **S+ \\
\hline $\begin{array}{l}\text { Low Education } \\
\text { Outpatient }\end{array}$ & NS & NS & $* * S+$ & NS & NS & NS & NS & $* * S+$ & NS \\
\hline treatment & NS & NS & NS & NS & NS & NS & $* \mathrm{~S}-$ & NS & $* * S+$ \\
\hline Constant & **S- & $* * S-$ & $* * S-$ & $* * S-$ & $* * S-$ & $* * S-$ & $* * S-$ & $* * S-$ & $* * S-$ \\
\hline
\end{tabular}

Note : S = Significant, NS = Not Significant, ** significant 5\%, *significant 10\% 
How to Lower the Poverty? Population Control...

Sartika Djamaluddin

Tabel 2c

Continued

\begin{tabular}{|c|c|c|c|c|c|c|c|c|c|}
\hline Variables & Bogor & Sukabumi & Bandung & Cirebon & Bekasi & Depok & Cimahi & Tasikmalaya & Banjar \\
\hline Region & & & & & & & & $* * S-$ & $* \mathrm{~S}$ \\
\hline \multicolumn{10}{|l|}{ SocialCharacteristics } \\
\hline Source of Livelihood & $* * S+$ & NS & $* * S+$ & NS & $* * S+$ & NS & NS & *S- & $* * S+$ \\
\hline \multicolumn{10}{|l|}{ Household Characteristics } \\
\hline \multicolumn{10}{|l|}{ Individual Characteristic } \\
\hline Agricultural & NS & NS & $* * S+$ & & & & NS & **S+ & NS \\
\hline Employment Status & NS & NS & NS & NS & NS & NS & NS & $* * S+$ & NS \\
\hline Low Education & $* * S+$ & $* * S+$ & $* * S+$ & $* * S+$ & $* * S+$ & NS & NS & $* * S-$ & NS \\
\hline Outpatient treatment & NS & NS & $* * \mathrm{~S}-$ & NS & & $* S+$ & NS & $* * S-$ & NS \\
\hline
\end{tabular}

Note : $\mathrm{S}=$ Significant, NS = Not Significant, ${ }^{* *}$ signifikan alpha 5\%, *signifikan alpha $10 \%$ 